\title{
Kelancaran Produksi ASI pada Ibu Post Partum Ditinjau dari Inisiasi Menyusu Dini dan Isapan Bayi
}

\author{
Hellen Febriyanti ${ }^{\left(1^{*}\right)}$, Wike Sri Yohanna ${ }^{(2)}$, Eva Nurida ${ }^{(3)}$ \\ ${ }^{1,2,3}$ Sekolah Tinggi Ilmu Kesehatan (STIKES) Aisyah Pringsewu Lampung \\ ${ }^{\left({ }^{*}\right)}$ hellenfebriyanti06@gmail.com; ${ }^{(2)}$ babeosake@gmail.com; ${ }^{(3)}$ evanuridaam@yahoo.com
}

ARTICLE INFO A B S T R A C T

Article history:

Received 11 February 2018

Revised 24 April 2018

Accepted 25 April 2018

Keyword:

Baby sucking

Breastmilk Production

Early Breastfeeding Initiation

(*) corresponding author

DOI:http://dx.doi.org/10.30604/jika.v3i1.74
The World Health Organization (WHO) recommends mothers with newborns infant to get colostrum from breast milk on the first and second day to protect and prevent various infections. Presurvey results showed from a total of 135 normal labor, there were 75 infants (55.6 percent) who did not do Early Initiation of Breastfeeding (IMD). This type of research is a quantitative research using analytical survey method, with cross sectional approach. The sample of research is 30 respondents. The result of chi square analysis showed the correlation of Early Initiation of Breastfeeding (IMD) with breastmilk production in post partum mother with p-value 0.009 ( $p<0.05)$ and $O R=19,000$. The result of chi square analysis of baby sucking variable with lactation on post partum mother obtained p-value 0,031, $(p<0,05)$ and $O R=$ 12,667. Based on the results of the study can be concluded that the lactation in post partum mothers associated with Initiation of Early Breastfeeding (IMD) and baby sucking. Suggested on post partum mother to increase knowledge such as counseling with health worker about the importance of Early Breastfeeding Initiation and training so that mother's milk production remain smoothly.

Copyright $\odot$ 2018, Jurnal Aisyah: Jurnal Ilmu Kesehatan. All rights reserved.

\section{PENDAHULUAN}

Salah satu yang di rekomendasikan World Healt Organization (WHO) kepada ibu supaya semua bayi mendapatkan kolostrum yaitu pada hari pertama dan kedua supayaterlindungi dan mencegah berbagai infeksi dan mendapatkan Air Susu Ibu ASI (Kemenkes, 2012). Pada awal bulan, bayi sangat berisiko terhadap berbagai penyakit. Air Susu Ibu (ASI) eksklusif membantu melindungi bayi dari penyakit diare dan infeksi umum lainnya. ASI diberikan minimal 6 bulan tanpa makanan pendamping ASI (PASI) inilah yang disebut dengan ASI eksklusif. ASI terdiri dari air, alfadaktoalbumin, laktosa, kasein, asam amino, antibodi terhadap kuman, virus dan jamur. Demikian juga ASI mengandung grouvthfactor yang berguna di antaranya untuk perkembangan mukosa usus. ASI akan melindungi bayi terhadap infeksi dan juga ASI dapat merangsang 
pertumbuhan bayi. Antibodi yang terkandung dalam air susu adalah imunoglobulin A (Ig A), bersama dengan berbagai sistem komplemen yang terdiri dari makrofag, limfosit, laktoferin, laktoperisidase, lisozim, laktoglobulin, interleukin sitokin, dan sebagainya (Proverawati \& Eni, 2010).

Pencapaian ASI eksklusif di Kabupaten Pringsewu pada tahun 2015 adalah 61,8 persen dengan target sebanyak 80 persen. Prasurvey yang dilakukan, terdapat 135 persalinan normal dimana terdapat 75 bayi (55,6 persen) yang tidak melakukan IMD dan yang tidak melakukan IMD 60 bayi (44,4 persen), serta dari hasil wawancara yang saya lakukan dengan bidan Fika Saumi, S. ST isapan bayi yang lemah dapat mengurangi kelancaran produksi ASI. dengan perbandingan di BPM Margiati, S.ST pada tahun 2016 terdapat 130 persalinan dari 130 bayi yang tidak dilakukan IMD sebanyak 30 bayi (23,1 persen) dan yang melakukan IMD sebanyak 100 bayi (76,9 persen), dan hasil wawancara dengan bidan Margiati, S.ST isapan bayi yang lemah akan menghambat kelancaran produksi ASI di desa Gadingrejo Kecamatan Gadingrejo kabupaten pringsewu.

Faktor yang mempengaruhi produksi ASI antara lain faktor makanan, ketenangan jiwa dan pikiran, penggunaan alat kontrasepsi, perawatan payudara, anatomi payudara. Faktor fisiologis, ASI terbentuk oleh karena pengaruh dari hormon prolaktin yang menentuan produksi dan mempertahankan sekresi air susu, pola istirahat. Faktor isapan bayi, isapan bayi yang efektif akan mengoptimalkan rangsangan ke otak yang akan memerintahkan untuk memproduksi hormon prolaktin dan oksitosin (Dewi, 2013).

Menurut Indriyani, dkk, (2009) bahwa untuk mengetahui banyaknya produksi ASI beberapa kriteria sebagai patokan untuk mengetahui jumlah ASI cukup atau tidak yaitu: ASI yang banyak dapat merembas keluar melalui puting, sebelum disusukan payudara terasa tegang, jika ASI cukup,setelah bayi menyusu bayi akan tertidur / tenang selama 3-4 jam, bayi BAK 6-8 kali dalam satu hari, bayi BAB 3-4 kali, bayi paling sedikit menyusu 8 sampai 10 kali dalam 24 jam, ibu mendengar suara menelan yang pelan ketika bayi menelan ASI, ibu dapat merasakan rasa geli karena aliran ASI setiap kali bayi mulai menyusu, warna urin bayi kuning jernih, dengan kategori kecukupan produksi ASI skor $\leq 6$ tidak lancar skor $\geq 6$ lancar (Soetjiningsih 1997, dalam Utari, 2014).

\section{METODE PENELITIAN}

Jenis penelitian ini kuantitatif, dengan menggunakan metode survey analitik dengan menggunakan pendekatan cross sectional, Populasi penelitian ini adalah Ibu post partum yang menyusui bayi sebanyak 30 responden di BPM Fika Saumi, S.ST Kecamatan Gadingrejo Kabupaten Pringsewu pada bulan Februari sampai Mei 2017, Penelitian ini menggunakan teknik total Sampling, sehingga tidak dilakukan pengambilan sampel.

Data dianalisis dengan menggunakan uji statistik Chi Square tidak memenuhi syarat sehingga dilanjutkan menggunakan Uji Square Exact dengan tingkat kemaknaan $\alpha$ $=0,05 \mathrm{H}_{0}$ ditolak jika $\rho<\alpha$, asumsi ada hubungan antara inisiasi menyusu dini dengan kelancaran produksi ASI serta ada hubungan antara isapan bayi dengan kelancaran produksi ASI.

\section{HASIL DAN PEMBAHASAN}

Tabel 1. Distribusi Frekuensi Kelancaran Produksi ASI Pada Ibu Post Partum

\begin{tabular}{lcc}
\hline $\begin{array}{c}\text { Kelancaran } \\
\text { Produksi ASI }\end{array}$ & Frekuensi & $\begin{array}{c}\text { Presentasi } \\
(\boldsymbol{\%})\end{array}$ \\
\hline Lancar & 20 & 66,7 \\
\hline Tidak Lancar & 10 & 33,3 \\
\hline Total & 30 & 100 \\
\hline
\end{tabular}


Berdasarkan tabel 1 diketahui dari $30 \mathrm{ibu}$ post partum terdapat 20 (66,6 persen) yang mengalami kelancaran produksi ASI dan 10 (33,3 persen) ibu postpartum yang tidak mengalami kelancaran produksi ASI.

Tabel 2. Distribusi Frekuensi IMD

\begin{tabular}{lcc}
\hline $\begin{array}{c}\text { Inisiasi Menyusu } \\
\text { Dini }\end{array}$ & Frekuensi & Presentasi (\%) \\
\hline IMD & 24 & 80 \\
\hline Tidak IMD & 6 & 20 \\
\hline Total & 30 & 100 \\
\hline
\end{tabular}

Berdasarkan tabel 2 diketahui dari $30 \mathrm{ibu}$ post partum terdapat 24 ( 80 persen) yang IMD dan 6 (20 persen) yang tidak IMD.
Tabel 3. Distribusi frekuensi isapan bayi pada ibu post partum

\begin{tabular}{lcc}
\hline \multicolumn{1}{c}{ Isapan Bayi } & Frekuensi & Presentasi (\%) \\
\hline Benar & 24 & 80 \\
\hline Tidak Benar & 6 & 20 \\
\hline Total & 30 & 100 \\
\hline
\end{tabular}

Berdasarkan Tabel 3 diketahui dari $30 \mathrm{ibu}$ post partum di BPM Fika Saumi S.ST di Kecamatan Gadingrejo Kabupaten Pringsewu terdapat 24 (80 persen) yang melakukan isapan benar dan 6 (20 persen) yang mengalami isapan tidak benar.

Tabel 4. Hubungan IMD dengan Kelancaran Produksi ASI pada Ibu Post Partum.

\begin{tabular}{|c|c|c|c|c|c|c|c|c|}
\hline \multirow{3}{*}{ IMD } & \multicolumn{4}{|c|}{ Kelancaran ASI } & \multirow{2}{*}{\multicolumn{2}{|c|}{ Total }} & \multirow{3}{*}{$p$ value } & \multirow{3}{*}{ OR CI 95\% } \\
\hline & \multicolumn{2}{|c|}{ Lancar } & \multicolumn{2}{|c|}{ Tidak lancar } & & & & \\
\hline & $\mathbf{N}$ & $\%$ & $\mathbf{N}$ & $\%$ & $\mathbf{N}$ & $\%$ & & \\
\hline IMD & 19 & 79,2 & 5 & 20,8 & 24 & 100 & \multirow[t]{3}{*}{0,009} & \multirow{3}{*}{$\begin{array}{c}19.000 \\
(1.790-201.681)\end{array}$} \\
\hline Tidak IMD & 1 & 16,7 & 5 & 83,3 & 6 & 100 & & \\
\hline Total & 20 & 66.7 & 10 & 33.7 & 30 & 100 & & \\
\hline
\end{tabular}

Berdasarkan tabel 4 dapat dilihat dari 30 responden, 24 responden yang melakukan IMD, 19 orang (79,2 persen) mengalami Kelancaran ASI dan 5 orang (20,8 persen) mengalami ASI tidak lancar, sedangkan dari 6 responden yang tidak melakukan IMD 1 (16,7 persen) mengalami ASI lancar dan 5 (83,3 persen) mengalami ASI tidak lancar.

Pada uji chi square didapatkan pvalue $=0.009<0,005$, artinya ada hubungan yang bermakna antara hubungan IMD dengan kelancaran produksi ASI, dan didapatkan nilai $\mathrm{OR}=19,000$ artinya $\mathrm{ibu}$ yangmelaukan IMD beresiko 19 kali mengalami ASI lancar dibandingkan dengan ibu yang tidak melakukan IMD.

Analisa Bivariat dilakukan untuk mengetahui hubungan variabel independen dengan variabel dependen yang diteliti yaitu Hubungan Inisiasi Menyusu Dini dan Isapan Bayi Dengan Kelancaran Produksi ASI sehingga diketahui kemaknaannya dengan menggunakan uji chi squuare.

Tabel 5. Hubungan Isapan Bayi dengan Kelancaran Produksi ASI pada Ibu Post Partum

\begin{tabular}{|c|c|c|c|c|c|c|c|}
\hline \multirow{3}{*}{ Isapan } & \multicolumn{4}{|c|}{ Kelancaran ASI } & \multirow{2}{*}{\multicolumn{2}{|c|}{ Total }} & \multirow{3}{*}{ p value } \\
\hline & \multicolumn{2}{|c|}{ Lancar } & \multicolumn{2}{|c|}{ Tidak lancar } & & & \\
\hline & $\mathbf{N}$ & $\%$ & $\mathbf{N}$ & $\%$ & $\mathbf{N}$ & $\%$ & \\
\hline Benar & 19 & 76 & 6 & 24 & 25 & 100 & 0,031 \\
\hline Tidak Benar & 1 & 20 & 4 & 80 & 5 & 100 & \\
\hline Total & 20 & 66.7 & 10 & 33.3 & 30 & 100 & \\
\hline
\end{tabular}


Berdasarkan tabel 5 dapat dilihat dari 30 responden, 25 responden yang melakukan isapan benar 19 (76 persen) yang mengalami kelancaran ASI dan 6 (24 persen) tidak lancar, sedangkan dari 5 responden yang melakukan isapan tidak benar terdapat 1 (20 persen) responden yang tidak mengalami kelancaran ASI dan 4 (80 persen) yang mengalami ASI tidak lancar. dengan hasil uji chi square didapatkan $\mathrm{p}$-value $=0,031<0,05$, artinya ada hubungan yang bermakna antara isapan bayi dengan kelancaran produksi ASI, dan di dapatkan nilai $\mathrm{OR}=12,667$, artinya bayi yang melakukan isapan benar beresiko 12 kali mengalami ASI lancar dibandingkan dengan bayi yang tidak melakukan isapan tidak benar.

\section{Inisiasi Menyusu Dini}

Berdasarkan tabel 2 diketahui dari 30 ibu post partum terdapat 24 (80 persen) yang IMD dan 6 (20 persen) yang tidak melakukan IMD di BPM Fika Saumi S.ST Kecamatan Gadingrejo Kabupaten Pringsewu supaya bayi mendapatkehanganyang disebabkan oleh kontak langsung dengan kulit ibu

Inisiasi Menyusu Dini adalah dilakukan kontak kulit dengan kulit dengan meletakkan bayibaru lahir diatas perut atau dada ibunya minimal 30 menit sampai bayi mencari sendiri puting susu ibunya dan langsung menyusu. Inisiasi menyusu dini dalam 30 menit pertama kelahiran dilakukan untuk mendukung 10 langkah keberhasilan menyusui berdasarkan inisiatif rumah sakit sayang bayi tahun 1992 (Astuti, 2015).

Inisiasi Menyusu Dini (IMD) adalah proses menyusu yang dimulai secepatnya. IMD dilakukan dengan cara membiarkan bayi kontak kulit dengan kulit ibunya setidaknya selama satu jam pertama setelah lahir atau hingga proses menyusu awal berakhir. Cara bayi melakukan IMD ini dinamakan the best craw atau merangkat mencari payudara
(Roesli, 2012 dalam Fikawati, 2015). Bagi ibu, Inisiasi Menyusu Dini (IMD) dapat mengoptimalkan pengeluaran hormon oksitosin, prolaktin, dan secara psikologis dapat menguatkan ikatan batin anatara ibu dan bayi (Prawirohardjo, 2014). Inisiasi Menyusu Dini (IMD) adalah proses menyusu yang dimulai secepatnya. IMD dilakukan dengan cara membiarkan bayi kontak kulit dengan kulit ibunya setidaknya selama satu jam pertama setelah lahir atau hingga proses menyusu awal berakhir. Cara bayi melakukan IMD ini dinamakan the best craw atau merangkat mencari payudara (Roesli, 2012 dalam Fikawati, 2015). Bagi ibu, Inisiasi Menyusu Dini (IMD) dapat mengoptimalkan pengeluaran hormon oksitosin, prolaktin, dan secara psikologis dapat menguatkan ikatan batin anatara ibu dan bayi (Prawirohardjo, 2014). Menurut asumsi peneliti IMD adalah tahap awal yang baik bagi bayi untuk melakukan kontak langsung dengan ibu, menurut sebagian orang awam berpendapat bahwa bayi baru lahir tidak mungkin dapat menyusu dan ASI ibu belum keluar, disini peran bidan di butuhkan untuk memberika informasi bahwa untuk mendapat ASI yang pertama kalinya bayi harus di bantu dengan memasukan puting susu ke mulut bayi dengan cara meletakkan bayi diatas perut ibupasca persalinan.

\section{Isapan Bayi}

Berdasarkan tabel 3 diketahui dari 30 ibu post partum terdapat 24 (80 persen) yang melakukan isapan benar dan 6 (20 persen) yang mengalami isapan tidak benar. Jika isapan bayi benar maka akan menstimulasi hipotalamus yang akan merangsang kelenjar hipofise anterior menghasilkan hormon prolaktin dan oksitosin Semakin sering bayi menyusu pada payudara ibu, maka produksi dan pengeluaran ASI akan semakin banyak akan tetapi, frekuensi penyusuan pada bayi prematur dan cukup bulan berbeda. Studi mengatakan bahwa pada produksi ASI bayi prematur akan 
optimal dengan pemompaan ASI lebih dari 5 kali per hari selama bulan pertama setelah melahirkan. Pemompaan dilakukan karena bayi prematur belum dapat menyusu. Sementara itu, pada bayi cukup bulan frekuensi penyusuan $10 \pm 3$ kali per hari selama minggu pertama setelah melahirkan, berhubungan dengan produksi ASI yang cakup. Oleh karena itu, direkomendasikan penyusuan paling sedikit 8 kali per hari pada periode awal setelah melahirkan. Frekuensi penyusuan ini berkaitan dengan kemampuan stimulasi hormon dalam kelenjar payudara (Dewi \& Tri, 2013).

Menurut asumsi peneliti pada bayi yang melakukan isapan benar akan mempengaruhi kelancaran produksi ASI karena rangsangan oleh yang dilakukan bayi ketika menggerakkan mulutnya akan menstimulasi hipotalamus yangakan merangsang kelenjar hipofise anterior menghasilkan hormon prolaktin dan hipofise posterior akan menghasilkan hormon oksitosin, sehingga produksi ASI akan lancar.

\section{Kelancaran Produksi ASI}

Berdasarkan Tabel 4.1 diketahui dari $30 \mathrm{ibu}$ post partum terdapat 20 (66,7 persen) yang mengalami ASI lancar, dan $10 \quad(33,3$ persen) yang mengalami ASI tidak lancar

ASI adalah makanan terbaik untuk bayi, ASI dibuat untuk bayi manusia. Kandungan gizi dari ASI sangat khusus dan sempurna serta sesuai dengan kebutuhan tumbuh kembang bayi (Dewi; 2013). ASI dihasilkan oleh kelenjar payudara wanita melalui proses laktasi. Keberhasilan laktasi ini dipengaruhi oleh kondisi sebelum dan saat kehamilan berlangsung. Kondisi sebelum kehamilan ditentukan oleh perkembangan payudara saat lahir dan pubertas. Kondisi pada saat kehamilan yaitu pada trimester II payudara mengalami pembesaran oleh karena pertumbuhan dan diferensiasi dari lobuloalveolar dan sel epitel payudara. Pada saat pembesaran payudara ini hormon prolaktin dan laktogen placenta aktif bekerja dalam memproduksi ASI (Proverawati \& Eni, 2010).

ASI dihasilkan oleh kelenjar payudara wanita melalui proses laktasi. Keberhasilan laktasi ini dipengaruhi oleh kondisi sebelum dan saat kehamilan berlangsung. Kondisi sebelum kehamilan ditentukan oleh perkembangan payudara saat lahir dan pubertas. Kondisi pada saat kehamilan yaitu pada trimester II payudara mengalami pembesaran oleh karena pertumbuhan dan diferensiasi dari lobuloalveolar dan sel epitel payudara. Pada saat pembesaran payudara ini hormon prolaktin dan laktogen plasenta aktif bekerja dalam memproduksi ASI (Proverawati \& Eni, 2010).

Menurut asumsi peneliti ibu yang mengalami produksi ASI tidak lancar adalah bayi yang tidak di IMD dan bayi yang melakukan isapan tidak benar, berdasarkan teori yang ada bahwa pada saat ibu dalam masa kehamilan payudara telah mengalami pembesaran dan hormon prolaktin dan lactogen plasenta aktif bekerja memproduksi ASI, sehingga ASI sudah terbentuk sejak ibu dalam masa kehamilan, IMD pada awal persalinan akan meransang bayi semakin cepat mengenali payudara ibu merupakasn salah satu yang harus diberitahu oleh tenaga kesehatan kepada ibu. Pentingnya ASI bagi bayi maka ibu harus banyak mendapatkan informasi sebanyak mungkin tentang apa saja yang dapat mempengaruhi kelancaran ASI, dari faktor makanan, cara menyusui yang benar maupun faktor apa saja yang dapat menghambat kelancaran produksi ASI, diharapkan ibu tidak megalami kesulitan dan mengalami komplikasi pada masa masa menyusui terutama pada ibu primipara karena ibu belum pernah mengalami sebelumnya. 


\section{Hubungan IMD dengan Kelancaran Produksi ASI Pada Ibu Post partum}

Berdasarkan tabel 4.4 di atas dapat di lihat dari 30 responden, 24 responden yang melakukan IMD 19 (79.2 persen) dan 5 (20.8 persen) yang mengalami ASI tidak lancar, sedangkan dar 6 responden 1 ( 16,7 persen) mengalami ASI lancar dan $5(83,3$ persen) mengalami ASI tidak lancar, dengan hasil uji chi square didapatkan pvalue $=0,009<0,05$ artinya ada hubungan yang bermakna antara IMD dengan kelancaran produksi ASI dan di dapatkan $\mathrm{OR}=19,000$ artinya ibu yang melakukan IMD beresiko 19 kali mengalami ASI lancar dibandingkan dengan ibu yang tidak melakukan IMD.

Hasil penelitian ini sejalan dengan penelitian Arini yang berjudul "hubungan Inisiasi Menyusu Dini Dengan Kelancaran Produksi ASI Pada Ibu Post Partum Di Desa Mranggen Kecamatan Jatinom Klaten" dengan hasil penelitian dimana terdapat hubungan yang bermakna antara inisiasi menyusu dini dengan produksi ASI pada ibu post partum dengan nilai $\mathrm{p}=$ 0,000 .

Inisiasi Menyusu Dini adalah dilakukan kontak kulit dengan kulit dengan meletakkan bayibaru lahir diatas perut atau dada ibunya minimal 30 menit sampai bayi mencari sendiri puting susu ibunya dan langsung menyusu. Inisiasi menyusu dini dalam 30 menit pertama kelahiran dilakukan untuk mendukung 10 langkah keberhasilan menyusui berdasarkan inisiatif rumah sakit sayang bayi tahun 1992 (Astuti, 2015).

Menurut asumsi peneliti terdapat hubungan antara Inisiasi Menyusu Dini dengan Kelancaran Produksi ASI, ada beberapa responden yang tidak melakukan IMD banyak yang mengalami ASI tidak lancar. karena IMD merupakan tahap awal yang baik untuk bayi melakukan kontak langsung antara kulit ibu dan kulit bayi untuk pertama kalinya berdasarkan teori diatas salah satu manfaat dari pemberian ASI dapat mengontraksikan otot-otot di sekeliling kelenjar ASI sehingga ASI dapat terpencar keluar, pada ibu yang tidak melakukan IMD salah satu disebabkan oleh bayi atau ibu yang mengalami komplikasi pada saat persalinan sehingga menunda atau tidak melakukan IMD, tetapi tidak semua responden yang tidak melakukan IMD mengalami produksi ASI tidak lancar karena faktor makanan bisa juga mempengaruhi produksi ASI dan ada responden yang melakukan IMD tetapi mengalami produksi ASI tidak lancar.

\section{Hubugan Isapan Bayi Dengan Kelancaran Produksi ASI}

Berdasarkan tabel 4.5 diatas dapat dilihat dari 30 responden, 25 responden yang melakukan isapan benar 19 ( 76 persen) mengalami ASI lancar dan 6 (24 persen) mengalami ASItidak lancar, sedangkan dari 4 responden yang melakukan isapan tidak benar 1 (20 persen) mengalami ASI lancar dan 4 (80 persen) mengalami ASI tidak lancar, dengan hasil uji chi square didapatkan $p$-value $=0,031<0,05$, artinya ada hubungan yang bermakna antara isapan bayi dengan kelancaran produksi ASI, dan di dapatkan nilai $\mathrm{OR}=12,667$, artinya bayi yang melakukan isapan benar beresiko 12 kali mengalami ASI lancar dibandingkan dengan bayi yang tidak melakukan isapan tidak benar.

Hasil penelitian di atas sejalan dengan penelitian sebelumnya yang dilakukan oleh tauriska yang berjudul hubungan antara isapan bayi dengan kelancaran produksi ASI pada ibu post partum dimana terdapat hubungan antara isapan bayi dengan kelancaran produksi ASI di peroleh dengan nilai $\mathrm{p}=0,018$.

Sesuai dengan teori menurut (Dewi \& Tri, 2013) ada beberapa faktor yang mempengaruhi isapan bayi yang dapat menyebabkan produksi ASI berkurang diantaranya puting susu lecet dapat disebabkan oleh trauma saat menyusui, 
selain itu dapat pula terjadi retak dan pembentukan celah-celah retakan pada puting susu dapat sembuh sendiri dalam waktu 48 jam, pada bayi prematur, Bayi dengan lidah pendek, puting melesak (masuk ke dalam), Labioschisis atau cleft tip atau bibir sumbing.

ASI pada ibu post partum yang menyusui mengalami kelancaran salah satu penyebabnya adalah isapan bayi yang benar inidapat dilihat dari cara ibu pada saat menyusui bayinya dan serta informasi yang didapat ibu dari tenaga kesehatan tentang bagaimana cara menyusui yang benar supaya bayi dapat menyusu dengan tenang dan mendapatkan ASI yang cukup dari ibu.

Adanya ibu post partum yang mengalami kelancaran produksi ASI ini dapat terjadi karena isapan bayi yang benar dapat membantu hormon prolaktin dalam memproduksi ASI serta ibu mencari tau kepada peugas kesehatan bagaimana cara agar bayi mendapatkan ASI yang ckup dan ibu mengalami ASI tidak lancar.

Menurut asumsi peneliti isapan yang benar akan mempengaruhi kelancaran produksi ASI, sesui teori diatas yang mengatakan jika isapan bayi benar maka akan menstimulasi hipotalamus yang akan merangsang kelenjar hipofise anterior menghasilkan hormon prolaktin dan oksitosin, karena rangsangan yang di lukaukan bayi, ketika menggerakan mulut saat menyusui akan mengsang hormon prolaktin untuk mengeluarkan ASI, sehingga dapat mempengaruhi kelancaran ASI, salah satu faktor penyebab isapan bayi tidak benar dikarnakan ibu malas untuk menyusui bayinya dan ibu yang kurang mengerti cara menyusui yang benar terhadap bayinya, tetapi tidak semua bayi yang tidak melakukan isapan benar mengalami ASI tidak lancar.

\section{SIMPULAN DAN SARAN}

Berdasarkan hasil penelitian dapat di tarik kesimpulan bahwa Distribusi Frekuensi Kelancaran Produksi ASI Pada Ibu Post Partum sebanyak 20 (66,6 persen). Distribusi Frekuensi Inisiasi Menyusu Dini sebanyak 24 (80,0 persen). Distribusi frekuensi isapan bayi pada ibu post partum di BPM Fika Saumi S.ST sebanyak 24 (80,0 persen). Ada hubungan bermakna bermakna antara IMD degan kelancaran produksi ASI pada ibu post partum dengan nilai $p$-value $=0.009$ dan $\mathrm{OR}=19.000$. Ada hubungan bermakna bermakna antara isapan bayi degan kelancaran produksi ASI pada ibu post partum dengan nilai $p$-value $=$ 0.031 dan $\mathrm{OR}=12.667$.

Dari penelitian ini penulis menyarankan kepada ibu post partum agar dapat lebih efektif lagi dalam mencari informasi tentang ASI sejak sebelum ibu melahirkan terutama kapada tenaga kesehatan supaya saat ibu melahirkan ibu dapat mengerti apa yang harus di lakukan pada bayi nya dari awal terutama tentang kebutuhan ASI terhadap bayinya.

BPM Fika Saumi. S.ST Diharapkan dapat melakukan penyuluhan atau konseling tentang pemberian ASI dari awal setelah persalinan sampai menyusui selanjutnya.

Saran bagi peneliti selanjutnya diharapkan dapat menjadi referensi bagi yang akan melakukan penelitian dengan menambahkan variabel lain yang berhubungan dangan variabel tergantung dengan sempel yang lebih banyak lagi. 


\section{DAFTAR PUSTAKA}

Arini, Meilani Yudi. (2013). Hubungan Inisiasi Menyusu Dini dengan Produksi ASI pada Ibu Post Partum di Desa Mragen Kecamatan Jatinom Klaten. Dalam Jurnal Komunikasi Kesehatan. ejurnal.akbid-purworejo.ac.id

Astuti, Sri., dkk. (2015). Asuhan Kebidanan Nifas dan Menyusui. Jakarta: Erlangga.

Dahlan, Sopiyudin. (2014). Statistik untuk Kedokteran dan Kesehatan (Edisi ke-6). Jakarta: Salemba Medika.

Dewi, Vivian Nanny Lia., Sunarsih, Tri. (2013). Asuhan Kebidanan pada Ibu Nifas. Jakarta: Salemba Medika.

Dinas Kesehatan Provinsi Lampung. (2015). Profil Kesehatan Provinsi Lampung Tahun 2015, Bandar Lampung.

Dinas Kesehatan Kabupaten Pringsewu. (2015). Profil Kesehatan Kabupaten Pringsewu Tahun 2015. Kabupaten Pringsewu.

Fikawati, Sandra dkk. (2015). Gizi Ibu dan Bayi. Jakarta: PT Raja Grafindo Persada.

Indriyani, Diyan., dkk. (2016). Edukasi Post Natal Dengan Pendekatan Family Centered Maternity Care. Yogyakarta: Trans Medika.

Notoadmodjo, Soekidjo. (2012). Metodelogi Penelitian Kesehatan. Jakarta: Rineka Cipta.

Proverawati, Atikah., Rahmawati, Eni. (2010). Kapita Selekta Asi dan Menyusui. Yogyakarta: Nuha Medika.
Prawirohardjo, Sarwono. (2014). Ilmu Kebidanan. Jakarta: PT Bina Pustaka.

Supomo, Ahmad. (2014). Profil Kesehatan Indonesia. http.//www. depkes.go.id. resources/ download/ pusdatin/ profil-kesehatan - indonesia/profilkesehatan-indonesia-2014.pdf

Soetjiningsih. (2014). ASI Petunjuk untuk Tenaga Kesehatan. Jakarta: EGC.

Tauriska, Tri Aprilia. (2014). "Hubungan Antara Isapan Bayi Dengan Produksi ASI Pada Ibu Menyusui di Rumah Sakit Islam Jemursari Surabaya". Dalam Tauriska, F Umamah-Journal of Health Sciences, 2016-journal.unusa.ac.id

Utami, Aris Puji. (2009). "Hubungan Inisiasi Menyusu Dini Dengan Kecepatan Keluarnya ASI pada Ibu Post Partum di BPS Firda Tuban". Dalam Jurnal Dosen, 2012 lppm.stikesnu.com.

Utari, Armina Puji. (2014). "Pengetahuan Gizi, Keluhan Kesehatan, Kondisi Psikologis dan Pola Pemberian Air Susu Ibu (ASI) Ibu Post Partum". Dalam http://repository.ipb.ac.id/handle/12 3456789/69170.

Walyani, Elisabet Siwi dan Endang Purwoastuti. (2015). Asuhan Kebidanan Masa Nifas dan Menyusui. Yogyakarta: Pustaka Baru Press. 